\title{
Delaney clause heads for the history books
}

Washington. The Delaney Clause - the controversial amendment in US food safety legislation banning the presence in processed foods of chemicals known to have a carcinogenic effect on animals, however low the risk - appears headed for the chopping block.

The Clinton administration, both Houses of Congress and officials at the Environmental Protection Agency (EPA), responsible for enforcing the act, agree the law needs to be updated, and Congressional action is likely over the next few months. But there is little consensus on what form the changes should take.

Fuelling the reform effort are pesticide manufacturers and food processors, who argue that the clause in the Federal Food, Drug and Cosmetic Act is excessively rigid and unscientific. But some environmental groups remain opposed to any changes, and want stronger enforcement of the clause.

The Delaney Clause, drafted in 1958 by James Delaney, a New York Congressman, bans the presence of carcinogenic pesticides in processed food - the so-called zero-risk standard. But the 1954 section of the food act still allows pesticide residues in raw food, with the agency being required to use risk-benefit analysis to set pesticide tolerance levels that take into account their commercial benefits.

Over time, the EPA found it difficult to enforce the strict standard laid out in Delaney, and in 1987, under the advice of the National Acade y of Sciences (NAS), stopped its literal interpretation of the law (although this has remained in force for the equally controversial application of the a mendment to food additives).

Instead, it began applying a "negligible risk" standard - defined as causing not more than one additional case of cancer among a million people - when setting tolerance levels of pesticides in both raw foods and processed foods. But the EPA continued its practice of automatically banning a pesticide in raw foods if it had already been outlawed in processed foods.

The academy concluded that modern scientific techniques made it virtually impossible for any processed food to pass the Delaney standard as it is written. It also claimed there was a conflict in the act between the standards applied to raw and processed foods, especially when a pesticide was used on crops headed both for the fresh food market and for processing.

Setting tolerances for pesticide uses has proved slow going for the EPA. The NAS has noted that EPA lacks scientific data on which pesticides are carcinogenic. Pesticides that were placed on the market before EPA began stricter enforcement of Delaney in 1978 have mostly been exempt from review, even though many are very carcinogenic.

Frustrated over what they claim to be a disregard for human safety, the Natural Resources Defense Council and other environmental groups took the agency to court in California, and won an order forcing it to interpret the law literally and complete a review of every pesticide use based on the law. According to the NRDC, the EPA had

\section{IMAGE UNAVAILABLE FOR COPYRIGHT REASONS}

Killing fields? US pesticide manufacturers are among those protesting against 'zero-risk' regulations.

reviewed only 27 of the 600 active ingredients used in making pesticides.

Under the terms of the court order, the EPA is supposed to revoke pesticides that do not comply with the food safety law, about 65 in total. So far, however, only one such use has been revoked; pesticide manufacturers and food processors have fought revocations in court, and have won nearly every case.

But the California verdict has still caused concern among agrochemical companies and food processors. The National Food Processors Association petitioned the EPA to relax its stance on chemicals in processed foods, and to stop simultaneous bans of pesticides in raw and processed foods.

One agricultural group says that a literal compliance of Delaney has already cost $\$ 400$ million nationwide. Jay Vroom, president of the American Crop Protection Association, says that his industry "will be forced to litigate every pesticide".

But NRDC says court action was the only

way to get the agency to act. "EPA's consistent approach throughout the 1980s with respect to carcinogens in food was to ignore or evade that historic statute," Erik Olson, counsel for the group, said last month.

The EPA, meanwhile, has argued that the terms of the order are misguided, as it forces the agency to remove some pesticides that are relatively safe in the quantities they are

\& typically found. Nonetheless, it says that o․ it will continue to enforce Delaney as is required by the California courts, and will do so until it is instructed otherwise by Congress. It will decide by December whether or not to end simultaneous bans.

Meanwhile, controversy is raging in 후 Congress over reforming Delaney. The Clinton administration introduced a proposal last year, drawing heavily on the NAS recommendations, that directs the EPA to apply a single standard of negligible risk, including non-cancer risks, to both raw and processed foods. The EPA would have to consider the harmful effects of pesticides on children and pesticide testing and safety checks would be strengthened.

But so far, the only legislator to have picked up the proposals is Henry Waxman (Democrat, California), who introduced a bill into the House of Representatives seeking tough new standards for children.

EPA officials are growing nervous over two alternative proposals, a pesticide reform bill drafted by Thomas Bliley (Republican, Virginia), backed by E. Kika de la Garza (Democrat, Texas) and a broad regulatoryreform bill drafted by Robert Dole in the Senate.

The administration is unhappy with both bills. Lynn Goldman, assistant administrator of EPA's Office of Prevention, Pesticides and Toxic Substances, has said that Clinton will not support the first of these unless it includes stronger enforcement measures and more emphasis on consumer safety. Clinton is not expected to sign the Dole bill as currently written.

Adrianne Appel

\section{Finn tipped for top Brussels research post}

Munich. Jorma Routti, the president of the Finnish high-technology promotion agency SITRA, is expected to be appointed later this month as the new director-general of the European Commission's research directorate. He will take over from the Italian Paolo Fasella in January.

Routti, who received a degree from the University of California at Berkeley, and remains a university professor, has a reputation in Finland as an efficient administrator with considerable experience in technology transfer.

SITRA's main task is to bridge the gap between research and industry by obtaining venture capital funding and cofinancing a system of cooperative networks between universities and industry.

Routti has also been at the centre of a shake-up in Finland's own research landscape over the past decade (see Nature $360,524 ; 1994)$. The country is now one of the highest investors in research among Europe's smaller economies and, partly as a result of SITRA's efforts, the share of its exports based on high technology has risen from 4 per cent in 1980 to 16 per cent last year.

Alison Abbott 